This is a revised personal version of the text of the final journal article, which is made available for scholarly purposes only, in accordance with the journal's author permissions. The full citation is:

Bárbara Rincón, Sonia Heaven, Charles J. Banks and Yue Zhang. (2012) Anaerobic Digestion of Whole-Crop Winter Wheat Silage for Renewable Energy Production. Energy \& Fuels 26 (4), 2357-2364.

DOI: $10.1021 /$ ef201985x

\title{
Anaerobic Digestion of Whole-Crop Winter Wheat Silage for Renewable Energy Production
}

\section{Author names and affiliations}

Bárbara Rincón ${ }^{\mathrm{a}, \mathrm{b}, *}$, Sonia Heaven ${ }^{\mathrm{a}}$, Charles J. Banks ${ }^{\mathrm{a}}$ and Yue Zhang ${ }^{\mathrm{a}}$.

${ }^{a}$ Faculty of Engineering and the Environment, University of Southampton, Southampton SO17 1BJ, UK.

${ }^{\text {b} I n s t i t u t o ~ d e ~ l a ~ G r a s a ~(C S I C), ~ A v d a . ~ P a d r e ~ G a r c i ́ a ~ T e j e r o ~ 4, ~} 41012$ Seville, Spain.

*Corresponding author. Tel: +34 954691526; Fax: +34 954691262. E-mail adress:

brlloren@cica.es (B. Rincón). Current address: Instituto de la Grasa (CSIC), Avda.

Padre García Tejero 4, 41012 Seville, Spain. 
ABSTRACT: With biogas production expanding across Europe in response to renewable energy incentives, a wider variety of crops need to be considered as feedstock. Maize, the most commonly used crop at present, is not ideal in cooler wetter regions where higher energy yields per hectare might be achieved with other cereals. Winter wheat is a possible candidate because, under these conditions, it has a good biomass yield, can be ensiled and used as whole crop material. The results showed that when harvested at the medium milk stage the specific methane yield was $0.32 \mathrm{~m}^{3} \mathrm{CH}_{4}$ $\mathrm{kg}^{-1} \mathrm{VS}$ added, equal to $73 \%$ of the measured calorific value. Using crop yield figures for the north of England a net energy yield of 146-155 GJ ha ${ }^{-1}$ year $^{-1}$ could be achieved after taking into account both direct and indirect energy consumption in cultivation, processing through anaerobic digestion, and spreading digestate back to land. The process showed some limitations, however: the relatively low density of the substrate made it difficult to mix the digester; there was a build-up of soluble chemical oxygen demand (COD) which represented a loss in methane potential, and may also have led to bio-foaming. The high nitrogen content of the wheat initially caused problems but these could be overcome by acclimatisation. A combination of these factors is likely to limit the loading that can be applied to the digester when using winter wheat as a substrate. 


\section{INTRODUCTION}

There is increasing interest in the production of biofuel using whole plant material, in which both the cellulose and hemicellulose fractions are biochemically converted to the fuel product. ${ }^{1}$ The production of methane through the anaerobic digestion process demonstrates this principle and has been widely adopted in Germany and Austria for biofuel production from whole crop maize ${ }^{2}$, often co-digested with animal slurry ${ }^{3}$. Conventionally grown maize can achieve a net energy production of $141 \mathrm{GJ} \mathrm{ha}^{-1}$ year $^{-1}$, assuming a biomass yield of 40 tonnes $\mathrm{ha}^{-1}$ year $^{-1}$ with a total solids content of $\sim 30 \%$ and taking into account direct and indirect energy inputs in cultivation and harvesting. ${ }^{4}$ Although maize is an ideal crop for central Europe where yields are particularly high, it may not be suited to other regions that experience wetter, cooler conditions, in which cereals such as wheat and barley give better yields. 5,6

The energy potential of whole crop materials has been studied in biochemical methane potential (BMP) tests, including different growth stages of maize, sunflower, triticale and winter rye ${ }^{2}$ and of winter wheat ${ }^{7}$. In testing for methane potential it is also important to consider the effect that storage may have on the crop and its methane yield. In practice harvested crops must be stored, and to achieve this they must either be dried in a hay-making process or made into silage by a combination of microbially-induced anaerobic conditions and acidity. Silage treatment is the most commonly used process for preservation of material harvested as a green 'whole crop' for forage ${ }^{8}$, although other methods such as alkaline treatment may also be considered ${ }^{9}$.

Since energy crops have mainly been digested as co-substrates with animal slurry ${ }^{3 \text {, }}$ 10,11 , there are relatively few studies using them as mono-substrates in long term trials with continuous or semi-continuous feeding. In the case of wheat, there are no reported 
studies of the methane production potential in semi-continuous fed digesters to determine the optimum loading rate and operating parameters. The objective of the current work was thus to establish the specific and volumetric methane yields and the operational stability of anaerobic digestion of winter wheat as a sole substrate, without addition of water, at different organic loading rates and associated retention times.

\section{MATERIALS AND METHODS}

Eight 5-litre digesters each with a working volume of 4 litres were used. These were constructed of uPVC tube with gas-tight top and bottom plates. The top plate was fitted with a gas outlet, a feed port sealed with a rubber bung, and a draught tube liquid seal through which an asymmetric bar stirrer was inserted with a $40 \mathrm{rpm}$ motor mounted directly on the top plate. Temperature was maintained at $35^{\circ} \mathrm{C} \pm 0.5$ by water circulating through an external heating coil. During semi-continuous operation digestate was removed through an outlet port in the base plate and feed added via the top plate. Gas

production was measured using tipping-bucket gas counters ${ }^{12}$ with continuous datalogging. Calibration of gas counters was checked weekly by collecting the gas in a Tedlar bag (SKC Ltd, Blandford Forum, UK): the volume was then measured accurately by weighing the water displaced when discharged into a weight-type gasometer. All gas volumes reported are corrected to standard temperature and pressure of $0^{\circ} \mathrm{C}, 101.325 \mathrm{kPa}$ in accordance with Walker et al. ${ }^{12}$

The substrate used was a variety of winter wheat (Triticum aestivum L.) harvested on 24 July at the medium milk harvest stage (moisture content $63.4 \%$ ) and preserved after collection with a silage treatment (Pioneer Hybrids 11A44 high dry matter Buchnerii innoculant) applied in accordance with the supplier's instructions. After 
collection from the farm on 28 February, the substrate was stored in $1 \mathrm{~kg}$ batches in sealed polythene bags at $-20{ }^{\circ} \mathrm{C}$. Substrate was defrosted as required and milled to a particle size of $0.5-1.5 \mathrm{~cm}$ before digestion, to ensure homogeneity in laboratory-scale operation.

The digesters were initially filled with inoculum collected from an anaerobic digester treating municipal wastewater biosolids (Millbrook, Southampton, UK). Before use the inoculum was sieved through a $1 \mathrm{~mm}$ mesh to remove large particles and grit. The inoculum had a total solids (TS) content of $29.1 \pm 0.4 \mathrm{~g} \mathrm{~kg}^{-1}$ and volatile solids (VS) content of $20.6 \pm 0.4 \mathrm{~g} \mathrm{~kg}^{-1}$.

The digesters were filled with $4 \mathrm{~kg}$ of sieved inoculum then left for 24 hours to allow consumption of residual organic matter. The digesters were then fed daily with a wet weight of wheat calculated to provide the desired organic loading rate. No water was added, in order to maintain a 'natural' retention time based on the substrate properties only. An amount of digestate was removed three times per week based on an estimated mass balance taking into account sampling and gas production. The digester was weighed each week and any necessary correction needed to maintain a constant weight was made by adjusting the mass of digestate removed over the following week. The digesters were initially fed at organic loading rates (OLR) of $\sim 2,3,4$, and $5 \mathrm{~g}$ $\mathrm{VS}_{\text {added }} \mathrm{l}^{-1}$ day $^{-1}$ and the operational conditions used in the trial are given in Table 1 . At the start of the trial each digester received $4 \mathrm{ml}$ of a trace element solution with the following composition: $\mathrm{FeCl}_{2} \cdot 4 \mathrm{H}_{2} \mathrm{O} 2 \mathrm{~g} \mathrm{l}^{-1}, \mathrm{CoCl}_{2} \cdot 6 \mathrm{H}_{2} \mathrm{O} 2 \mathrm{~g} \mathrm{l}^{-1}, \mathrm{MnCl}_{2} \cdot 4 \mathrm{H}_{2} \mathrm{O} 0.5 \mathrm{~g} \mathrm{l}^{-1}$, $\mathrm{CuCl}_{2} \cdot 2 \mathrm{H}_{2} \mathrm{O} 38 \mathrm{mg} \mathrm{l}^{-1}, \mathrm{ZnCl}_{2} 50 \mathrm{mg} \mathrm{l}^{-1}, \mathrm{H}_{3} \mathrm{BO}_{3} 50 \mathrm{mg} \mathrm{l}^{-1,}\left(\mathrm{NH}_{4}\right)_{6} \mathrm{Mo}_{7} \mathrm{O}_{24} \cdot 4 \mathrm{H}_{2} \mathrm{O} 50 \mathrm{mg} \mathrm{l}^{-}$ ${ }^{1}, \mathrm{Na}_{2} \mathrm{SeO}_{3} \cdot 5 \mathrm{H}_{2} \mathrm{O} 194 \mathrm{mg} \mathrm{l}^{-1}, \mathrm{AlCl}_{3} \cdot 6 \mathrm{H}_{2} \mathrm{O} 90 \mathrm{mg} \mathrm{l}^{-1}, \mathrm{NiCl}_{2} \cdot 6 \mathrm{H}_{2} \mathrm{O} 50 \mathrm{mg} \mathrm{l}^{-1}$, EDTA $1 \mathrm{~g} \mathrm{l}^{-1}$ and resazurin $200 \mathrm{mg} \mathrm{l}^{-1} .^{13}$ 
Samples of digestate were analysed for $\mathrm{pH}$, alkalinity, TS and VS content, total Kjeldahl nitrogen (TKN), total ammoniacal nitrogen (TAN) and VFA concentration. Gas volumes were recorded daily and gas composition was determined by gas chromatography twice per week.

2.1. Analytical methods. Total and volatile solids were measured using Standard Method 2540 G. ${ }^{14}$ Alkalinity was measured by titration with $0.25 \mathrm{~N} \mathrm{H}_{2} \mathrm{SO}_{4}$ to endpoints of $\mathrm{pH} 5.75$ and 4.3, to allow calculation of partial alkalinity (to $\mathrm{pH} 5.75$ ), total alkalinity (to $\mathrm{pH} 4.3$ ), and intermediate alkalinity (between $\mathrm{pH} 5.75$ and 4.3$)^{15}$. Total Kjeldahl Nitrogen (TKN) was determined using reflux digestion and steam distillation and digestate TAN was measured by steam distillation, in both cases according to the equipment manufacturer's instructions (Foss Ltd, Warrington, UK). Volatile fatty acids (VFA) were quantified in a Shimazdu GC-2010 gas chromatograph (Shimadzu, Milton Keynes, UK), using a flame ionization detector and a capillary column type SGE BP21. Biogas composition was analysed using a Varian CP 3800 gas chromatograph (GC) with a gas sampling loop, with argon as the carrier gas at a flow of $50 \mathrm{ml} \mathrm{min}^{-1}$. The GC was fitted with a Hayesep C column and a molecular sieve 13 x (80-100 mesh) operating at a temperature of $50{ }^{\circ} \mathrm{C}$. The $\mathrm{GC}$ was calibrated using a standard gas containing $35 \% \mathrm{CO}_{2}$ and $65 \% \mathrm{CH}_{4}$ (BOC, Guildford, UK).

Further characterisation was carried out on samples prepared by air drying to constant weight and then milled to a particle size $\leq 0.5 \mathrm{~mm}$ in a micro hammer mill (Glen Creston Ltd, Standmore Mill, UK). Fibre composition, expressed as Neutral Detergent Fibre (NDF), Acid Detergent Fibre (ADF) and Acid Detergent Lignin (ADL), was measured using the FibreCap ${ }^{\mathrm{TM}} 2021 / 2023$ system (Foss Analytical, Warrington, UK) following the method given by Kitcherside et al. ${ }^{16}$. Elemental Analysis (C, H, N) was carried out using a Flash EA 1112 machine (Thermo Finnigan, Hemel Hempsted, 
UK) following the manufacturer's recommended procedure with L-Aspartic Acid, Atropine and Nicotinamide as standards. Phosphorus (P) was determined using the ascorbic acid spectrophotometry method $4500-\mathrm{PE}^{14}$, with measurements taken at 880 nm using a Cecil 3000 Series Spectrophotometer (Cecil Instruments, Cambridge, UK). An acid extract of the air-dried material was microwave digested with nitric acid (Microwave Accelerated Reaction System, Model MARS X ${ }^{\mathrm{R}}$, XP-1500 Plus, CEM Corporation). The extract was filtered and diluted to $50 \mathrm{ml}$ with deionised water (MilliQ Gradient, Millipore, Watford, UK) and $\mathrm{Cd}, \mathrm{Cr}, \mathrm{Cu}, \mathrm{K}, \mathrm{Ni}, \mathrm{Pb}$, and $\mathrm{Zn}$ determined using a flame atomic absorption spectrometer (Spectr AA-200, Varian, USA) according to the manufacturer's procedures and against appropriate stock standards (Sigma Aldrich Co, Gillingham, UK; Fisher Scientific, Loughborough, UK).

2.1.1. Solids destruction and energy values. VS destruction rates were calculated based on a mass balance of solids in the influent and effluent, but without taking into account changes in storage within the digester. Before steady state conditions are established, these values are best described as an apparent VS destruction. For this purpose it was assumed that the wet weight of digestate removed was equal to the wet weight of feedstock added, minus the weight of biogas removed. The weight of biogas removed was estimated from the weekly average volume and gas composition in terms of $\% \mathrm{CH}_{4}$ and $\mathrm{CO}_{2}$, ignoring water vapour and other gases.

The Buswell equation ${ }^{17}$ was used to calculate the theoretical methane yield of the wheat samples based on elemental composition, with $\mathrm{O}$ estimated by assuming $\mathrm{C}+\mathrm{H}+\mathrm{O}+\mathrm{N}=99.5 \%$ on a VS basis. Theoretical CV was calculated using the Du Long equation according to the method in Combustion File $24^{18}$, and a higher heat value for

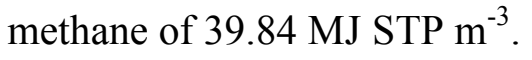




\section{RESULTS}

3.1. Feedstock Characteristics. The characteristics of the ensiled wheat feedstock are given in Table 2. The $\mathrm{pH}$ was 4.2 as a result of lactic fermentation during the silage storage. The TKN was $6.4 \mathrm{~g} \mathrm{~N} \mathrm{~kg}^{-1}$ wet weight (WW), TAN was $1.3 \pm 0.0 \mathrm{~g} \mathrm{~N} \mathrm{~kg}^{-1} \mathrm{WW}$ and phosphorus $0.74 \pm 0.04 \mathrm{~g} \mathrm{P} \mathrm{kg}^{-1} \mathrm{WW}$. The moisture content was $63.4 \% \mathrm{WW}$, lignin content was relatively low at $8.9 \% \mathrm{TS}$, and the carbon to nitrogen $(\mathrm{C} / \mathrm{TKN})$ ratio was 25. Further characterisation of the wheat used (identified as Wheat A) and determination of its Biochemical Methane Potential (BMP) was carried out by Rincón et al. $^{7,9}$

3.2. Digestion trials. Digesters R1 and R2 (OLR $2.1 \mathrm{~g} \mathrm{VS}^{-1}$ day $\left.^{-1}\right)$ were successfully operated over the full experimental period of 420 days, equivalent to around 2.5 times the 'natural' retention time. Digesters R3 and R4 (OLR 3.1 $\mathrm{g} \mathrm{VS}^{-1}$ day $^{-1}$ ) operated smoothly until day 114 when the gas venting line in R4 blocked due to foaming, causing a loss of $\sim 1.6 \mathrm{~kg}$ of digestate. Feeding of R4 was continued at the same OLR until day 420 (around 3.8 retention times) but maintaining the reduced volume, with a corresponding increase in digester headspace. On day 288 a similar but even more extensive loss occurred in R3 and feeding of this digester was stopped.

Digesters R5 and R6 (OLR 4 g VS $1^{-1}$ day $^{-1}$ ) ran for 70-80 days ( $\sim 1.2$ retention times) before signs of failure became evident and feeding was stopped. It was not possible to operate digesters R7 and R8 successfully at the highest OLR of $5 \mathrm{~g} \mathrm{VS}$ added $1^{-1}$ day $^{-1}$. Winter wheat is a lightweight substrate and the volume of daily feed corresponding to the $60 \mathrm{~g} \mathrm{WW} \mathrm{d}^{-1}$ required by $\mathrm{R} 7$ and R8 was very large. This led to problems in stirring, accompanied by entrainment of biogas and blockage of gas lines. It was only possible to 
run these digesters for a period of 26 days and no consistent analytical or monitoring results were obtained.

3.2.1. $\mathrm{pH}$ and alkalinity. The $\mathrm{pH}$ at the start of the trial was 7.90 and showed a slight initial decrease to between 7.50-7.70 from day 16 to day 120 in all digesters (Figure 1a). After this the $\mathrm{pH}$ rose in digesters R1-R4 and fluctuated around 8.20-8.40 till the end of the run, except for a brief fall around day 223 to $\mathrm{pH} 8.00$. For R5 and R6 (OLR $4 \mathrm{~g} \mathrm{VS}^{-1}$ day $^{-1}$ ) $\mathrm{pH}$ values remained similar to those in the other digesters until day 50 then fell sharply to 6.0 and 5.7 by day 84 and 72 respectively, at which point methanogenesis was inhibited.

Figure $1 \mathrm{~b}$ shows the alkalinity in digesters R1-4. At an OLR of $2.1 \mathrm{~g} \mathrm{VS}^{-1}$ day $^{-1}$ the partial alkalinity (PA), which indicates the bicarbonate buffering available in the digester, rose from $4.0 \mathrm{~g} \mathrm{CaCO}_{3} \mathrm{1}^{-1}$ to 9.25 for $\mathrm{R} 1$ and to $8.75 \mathrm{~g} \mathrm{l}^{-1}$ for $\mathrm{R} 2$ by day 150 , and appeared to stabilise at around 12.5-13.0 $\mathrm{g}^{-1}$ in both digesters by day 350 . Total alkalinity (TA), which includes both bicarbonate and VFA buffering ${ }^{15}$, also increased from $6.0 \mathrm{~g} \mathrm{CaCO}_{3} \mathrm{l}^{-1}$ to 12.5 and $11.25 \mathrm{~g} \mathrm{l}^{-1}$ for $\mathrm{R} 1$ and $\mathrm{R} 2$ respectively in the first 150 days, stabilising around $17.0 \mathrm{~g} \mathrm{1}^{-1}$. The intermediate to partial alkalinity ratio (IA/PA) (Figure 1d) rose to around 0.6 between day $131-170$ in R1, with a similar but slightly delayed peak of around 0.55 between day $200-226$ in R2. As the intermediate alkalinity (IA) reflects the VFA buffering, this ratio provides a very sensitive indicator of digestion stability. The IA/PA ratio for the last 100 days of operation averaged 0.31 in $\mathrm{R} 1$ and 0.37 in $\mathrm{R} 2$, close to the classic value for stable operation ${ }^{15}$. In digesters R3 and $\mathrm{R} 4$ at the OLR of $3.1 \mathrm{~g} \mathrm{VS}^{-1}$ day $^{-1}$ a similar pattern was observed but with a slightly higher TA during the initial period. Stable values of both PA and TA were observed over the final 50 and 150 days of operation in R3 and R4, with IA/PA ratios of 0.61 and 0.41 respectively. 
In R5 and R6 (OLR $4 \mathrm{~g} \mathrm{VS}^{-1} \mathrm{~d}^{-1}$ ) PA increased to $7.0 \mathrm{~g}^{-1}$ after 28 days, and then fell steadily to final values of 2.99 and $2.67 \mathrm{~g} \mathrm{l}^{-1}$ (Figure 1c). TA remained constant at around $10 \mathrm{~g} \mathrm{l}^{-1}$ from day 28 on, with an accompanying rise in intermediate alkalinity. This resulted in increases in the IA/PA ratio to 2.63 and 2.94 on days 85 and 60 in R5 and R6 respectively (Figure 1d), due to rising VFA concentrations that ultimately reduced the $\mathrm{pH}$ to less than 6 , resulting in digester failure. While this failure occurred slightly earlier and more rapidly in R6, the two reactors showed similar behaviour.

3.2.2. Ammoniacal and Kjeldahl Nitrogen. The measured TKN concentration in the substrate was $6.4 \mathrm{~g} \mathrm{~kg}^{-1} \mathrm{WW}$, but the expected concentration in the digestate is higher due to the breakdown of solids. The feedstock VS concentration was $347 \mathrm{~g} \mathrm{VS} \mathrm{kg}^{-1}$ WW. Assuming 75\% VS destruction the residual quantity of digestate from $1 \mathrm{~kg}$ feedstock is equal to $(1000-0.75 \times 347)=740 \mathrm{~g} \mathrm{WW}$, and the predicted TKN concentration under steady-state conditions is thus $6.4 * 1000 / 740=8.6 \mathrm{~g} \mathrm{TKN} \mathrm{kg}^{-1}$ WW, which corresponded closely to the final measured value in R4 (Figure 2a). TKN and TAN concentrations in all digesters were modelled on a simple mass balance basis, assuming digestate concentrations of $8.6 \mathrm{~g} \mathrm{TKN} \mathrm{kg}^{-1} \mathrm{WW}$ and $4.75 \mathrm{~g} \mathrm{TAN} \mathrm{kg}^{-1} \mathrm{WW}$ respectively. It can be seen that both R1-2 and R3-4 were close to steady state concentrations by the end of trial (Figure $2 b$ and c). The correlation coefficient between measured and modelled values for TAN was $R^{2}=0.98$ (all measurements, $n=152$ ); the value for TKN was slightly lower at $\mathrm{R}^{2}=0.78$ for all digesters $(\mathrm{n}=62)$ and 0.93 for $\mathrm{R} 3$ and $4(\mathrm{n}=24)($ Figure $2 \mathrm{~d})$. The goodness of fit of this simple model suggests that there is a fairly rapid breakdown of incoming nitrogen-containing material which releases $\sim 55 \%$ of the measured TKN as ammoniacal nitrogen within a short period. This high TAN concentration contributes to the high alkalinity noted and therefore provides buffering able to protect against accumulations of VFA. 
3.2.3. Solids. Figure 3a shows the evolution of digestate TS content over time for all digesters. The rate of increase from initial values of around $34 \mathrm{~g} \mathrm{TS} \mathrm{kg}^{-1} \mathrm{WW}$ again reflects the OLR in each case. Values in R2 and R4 had equalised by around day 350 , while R1 appeared to be lagging slightly behind R2 but reached a similar concentration of $140 \mathrm{~g} \mathrm{TS} \mathrm{g}^{-1} \mathrm{WW}$ by the end of the experimental period. From day $119 \mathrm{TS}$ concentrations in R3 were consistently higher than those in R4 by around $15 \mathrm{~g} \mathrm{TS} \mathrm{kg}^{-1}$ WW, while in the last 50 days before feeding ceased there was a further increase in R3 to around $147 \mathrm{~g} \mathrm{TS} \mathrm{kg}^{-1} \mathrm{WW}$, possibly associated with the failure, and equivalent to the final concentration in R1, R2 and R4. VS concentrations (Figure 3b) showed a closely similar pattern to TS. Apparent VS destruction rates are shown in Figure $3 \mathrm{c}$ and appeared to be stabilising at around $75 \%$ in R1, R2 and R4 towards the end of the experimental period, confirming the values based on digestate TKN: the higher solids concentration in R4 before failure is reflected by the earlier onset of reduced VS destruction. TS, VS and associated apparent removal rates in R5 and R6 are shown in Figure $3 \mathrm{~d}$ and indicate a slightly lower rate of acclimation

\subsubsection{VFA and SCOD. VFA concentrations in $\mathrm{R} 1$ and $\mathrm{R} 2$ remained at fairly low} values generally $<200 \mathrm{mg} \mathrm{l}^{-1}$ for over 120 days, after which there was a sharp increase in acetic acid accompanied by smaller increases in propionic and iso-valeric concentrations (Figure $4 \mathrm{a}$ and $\mathrm{b}$ ). The reactors appeared to overcome this accumulation after a further 50-60 days when VFA concentrations started to fall. Acetic acid did not return to the previous low concentration, however, but fluctuated between $\sim 500-1250$ $m g 1^{-1}$ for the rest of the experimental period. A similar pattern was observed in R3 and R4 but with the increase in acetic acid starting from day $~ 50$ and peaking close to 6000 $\mathrm{mg}^{-1}$ around day 112 in both digesters. Increases in propionic and iso-valeric acid were also seen (Figure 4c and d). Again there was a recovery to a residual concentration of 
acetic acid similar to that in R1 and 2. In R5 and 6, acetic acid accumulation began even earlier at around day 38 , and reached concentrations of $\sim 13000 \mathrm{mg}^{-1}$ by around day 80 (Figure 4e and f). This concentration was sufficient to overcome the digester buffering capacity, leading to the fall in $\mathrm{pH}$ and increase in IA/PA noted above, and to failure of digestion.

The increase in VFA occurred earlier in the higher loaded reactors, but did not directly correlate to HRT. The sudden onset of VFA accumulation after a period of relatively stable operation can be indicative of accumulation of some component inhibitory to part of the microbial population, or of the washout of an essential element that may impair enzyme function, in both cases interrupting the flow of carbon through to methane. As the acetic acid peak decreased without any further build-up of VFA, it is possible that there was a change in the structure of the methanogenic population: similar acetic acid peaks have been observed in other studies associated with a shift in dominance from acetoclastic to hydrogenotrophic methanogens. ${ }^{19}$ This shift can be associated with an increase in digestate TAN concentration, which is known to be more toxic to the acetoclastic population..$^{20,21}$ Ammonia toxicity depends on a number of factors, including $\mathrm{pH}$ and temperature which determine the equilibrium between free ammonia and dissociated ionic ammonium. TAN concentrations at the onset of VFA accumulation were around 3000, 2300 and $2400 \mathrm{mg} \mathrm{l}^{-1}$ in R1-2, R3-4 and R5-6 respectively: free ammonia concentrations are highly sensitive to $\mathrm{pH}$ but values at this time were below $300 \mathrm{mg}^{-1}$ in all digesters. As TAN concentrations increase the acetoclastic population is gradually lost and hydrogenotrophic activity takes over, with acetic acid converted to $\mathrm{CO}_{2}$ via the reverse Wood-Ljundahl pathway. ${ }^{21,22}$ This would explain the decrease in the acetic acid peak and the continued functioning of digesters R1-4 at TAN concentrations approaching $4500 \mathrm{mg} \mathrm{l}^{-1}$. The higher loading on R5 and 6 
gave the reactors relatively little time to adapt to these changing conditions, and a longer acclimation period may have allowed successful operation at the OLR of $4 \mathrm{~g}$ VS $1^{-1}$ day $^{-1}$.

SCOD accumulated through the experimental period in all digesters. The majority of this could not be accounted for by accumulation of VFA up to heptanoic acid (C7), as SCOD concentrations appeared to stabilise at around $60 \mathrm{~g}^{-1}$ in $\mathrm{R} 1$ and 2 by the end of the run. One possible explanation for the SCOD is from the build-up of soluble microbial products: these are associated with long solids retention times, and may account for the foaming observed. ${ }^{23,24}$ SCOD can also result from the solubilisation and non-degradation of organic material present in the substrate, such as lignin. If the lignin present in the feedstock was released from solid state through the breakdown of

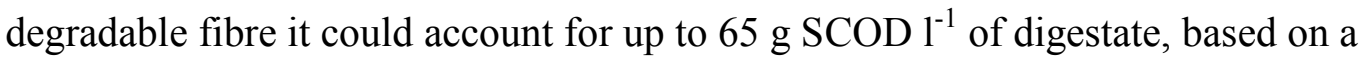
theoretical SCOD for lignin of $1.85 \mathrm{~g} \mathrm{~g}^{-1} \cdot{ }^{25}$

3.2.5. Methane production. Specific and volumetric methane productions are shown in Figure 5. Initially there was some fluctuation in specific biogas and methane yields reflecting the changing reactor conditions, in particular the observed peaks in VFA concentration. In the latter part of the study from day $\sim 250$ onwards the specific methane yields in R1-2 and R4 were closely similar at $0.3201 \mathrm{CH}_{4} \mathrm{~g}^{-1} \mathrm{VS}_{\text {added }}$; R3 appeared to be recovering around day 200 but the specific methane yield then fell slightly, corresponding to the reduced solids destruction in the period before failure. Specific methane yield based on the volatile solids destruction in R1-2 and R4 was $\sim 0.43 \mathrm{I} \mathrm{CH}_{4} \mathrm{~g}^{-1} \mathrm{VS}$ destroyed, slightly greater than the theoretical value for cellulose. The average methane concentration was 53\%. The volumetric methane yields reflected the loading rates, with $\mathrm{R} 3$ and 4 achieving a value of around $1.81 \mathrm{CH}_{4} \mathrm{l}^{-1}$ reactor day ${ }^{-1}$. 
Table 3 summarises some key energy production parameters. The theoretical methane yield calculated from the Buswell equation ${ }^{17}$ was $0.4511 \mathrm{CH}_{4} \mathrm{~g}^{-1} \mathrm{VS}$ respectively: the measured value corresponds to about $71 \%$ of this, reflecting the VS destruction of about $75 \%$. The theoretical and measured calorific values were in reasonably good agreement, confirming the elemental analysis results. The recovery of energy as methane corresponded to $73.3 \%$ and $68.7 \%$ of the measured and theoretical calorific values, respectively. The specific methane yield in semi-continuous digestion was about $12 \%$ less than the BMP value of $0.361 \mathrm{CH}_{4} \mathrm{~g}^{-1} \mathrm{VS}$ as determined by Rincón et al. $^{7}$ for the same batch of material. This difference is greater than expected given the long retention times, and it is possible that some of the methane potential was present in the accumulated SCOD which at steady-state conditions had reached concentrations of $\sim 60 \mathrm{~g} \mathrm{l}^{-1}$. The amount of SCOD removed in the digestate each day would have a theoretical methane yield of $0.0461 \mathrm{~g}^{-1} \mathrm{VS}_{\text {added }}$, which if added to the actual specific methane yield gives a total of $0.3661 \mathrm{CH}_{4} \mathrm{~g}^{-1} \mathrm{VS}_{\text {added, }}$, very close to the BMP value. This may favour soluble microbial products (SMP) rather than lignin as the source of the undegraded SCOD, as the SMP may not form or may be successfully broken down in the batch test.

Whole crop winter wheat is ideal for growing in cooler and wetter climates. With a biomass yield of around 40 tonnes wet weight ha- year $^{-19}$ and a specific methane yield of $0.3201 \mathrm{CH}_{4} \mathrm{~g}^{-1} \mathrm{VS}_{\text {added, }}$, the gross energy yield from anaerobic digestion of the current material based on a lower heat value for methane of $35.8 \mathrm{MJ} \mathrm{m}^{-3}$ is thus around $160 \mathrm{GJ} \mathrm{ha}^{-1}$ year ${ }^{-1}$. Using the methods described in Rincón et al. ${ }^{9}$ the total input energy for crop production can be estimated as $13.7 \mathrm{GJ} \mathrm{ha}^{-1}$ with mineral fertilisers or $4.7 \mathrm{GJ}$ $\mathrm{ha}^{-1}$ if cattle slurry is used as fertiliser, giving net energy yields of around 146 or $155 \mathrm{GJ}$ $\mathrm{ha}^{-1}$ year $^{-1}$. There may however be some disadvantages in using winter wheat as an 
energy crop for anaerobic digestion. These are related to its high nitrogen content which may cause instability during the acclimatisation period. More problematic are the difficulties in processing the material due to its physical characteristics and tendency to bio-foaming, which may ultimately limit the loading that can be applied in practice.

\section{CONCLUSIONS}

Semi-continuous anaerobic digestion of winter wheat showed high volatile solids destruction, an important property for an arable energy crop, and a biogas methane content typical of cellulosic crop materials. The substrate TKN and the accumulation of TAN in the digesters indicated that whole crop wheat has a higher protein content than maize, which is more commonly used as an energy crop for biogas production. This high nitrogen content caused some temporary digester instability, as the TAN concentration rose above the inhibitory threshold for acetoclastic methanogenesis: the volatile fatty acid accumulation observed was probably due to a shift in the methanogenic population from acetoclastic to hydrogenotrophic. Gross and net energy yields indicated that, where annual per hectare yields of wheat are higher than can be achieved with other cereal crops for climatic or geographical reasons, it may be a suitable choice for energy production as a whole crop material. The material is more difficult to work with than some alternative crops, however, as its relatively low density and tendency to bio-foaming can lead to problems in reactor operation and mixing. At the long retention times applied there was also accumulation of SCOD, representing a loss in substrate specific methane yield. 


\section{AUTHOR INFORMATION}

Corresponding author: Tel: +34 954692516; Fax: +34 954691262. E-mail adress:

brlloren@cica.es (B. Rincón).

Current address: Instituto de la Grasa (CSIC), Avenida Padre García Tejero 4, 41012 Seville, Spain.

\section{ACKNOWLEDGMENTS}

This work was partially funded by the Research Councils UK Rural Economy and Land Use (RELU) programme (RES-229-25-0022). The authors also wish thank the Secretaría de Estado de Universidades e Investigación of the Spanish Education and Science Ministry, the Fundación Española para la Ciencia y la Tecnología and the contracts JAE-Doc from "Junta para la Ampliación de Estudios del CSIC" co-financed by the European Social Funds for supporting Dr. Rincón; and Peter King of KingBros for supplying wheat samples.

\section{REFERENCES}

(1) Londo, M.; Lensink, S.; Wakker, A.; Fischer, G.; Prieler, S.; Van Velthuizen, H.; Marc De Wit, F., A.; Junginger, M.; Berndes, G., Hansson, J.; Egeskog, A.; Duer, H., Lundbaek, J.; Wisniewski, G.; Kupczyk, A.;Könighofer, K. Biomass Bioenergy. 2010, $34(2), 244-250$.

(2) Amon, T.; Amon, B.; Kryvoruchko, V.; Machmüller, A.; Hopfner-Sixt, K.;

Bodiroza, V.; Hrbek, R.; Friedel, J.; Pötsch, E.; Wagentristl, H.; Schreiner, M.;

Zollitsch, W. Bioresour. Technol. 2007, 98 (17), 3204-3212. 
(3) Holm-Nielsen, J.B.; Al Seadi, T.; Oleskowicz-Popiel, P. Bioresour. Technol. 2009, $100,5478-5484$.

(4) Salter, A.; Banks, C.J. Water Sci. Technol. 2009, 59 (6), 1053-1060.

(5) Leff, B.; Ramankutty, N.; Foley, J.A. Global Biogeochem. Cycles. 2004, 18 GB1009.

(6) FAO. 2011. FAOSTAT, http://faostat.fao.org/site/339/default.aspx, last accessed 25/11/2011.

(7) Rincón, B.; Banks, C.J.; Heaven, S. Bioresour. Technol. 2010, 101 (21), 81798184.

(8) Yang, X.; Chen, H.; Gao, H.; Li, Z. Bioresour. Technol. 2001, 78 (3), 277-280.

(9) Rincón, B.; Heaven, S.; Salter, A.M.; Banks, C.J. 2011, Comparison of the net energy yield from anaerobic digestion of Spring and Winter wheat. 6th IWA International Symposium on Anaerobic Digestion of Solid Waste and Energy Crops. 28 August - 1 September 2011, Vienna.

(10) Weiland, P. Biodegradation. 2000, 11 (6), 415-421.

(11) Amon, T.; Amon, B.; Kryvoruchko, V.; Zollitsch, W.; Mayer, K.; Gruber, L. Agric. Ecosyst. Environment. 2007, 118 (1-4), 173-182.

(12) Walker, M.; Zhang, Y.; Heaven, S.; Banks, C.J. Bioresour. Technol. 2009, 100 (24), 6339-6346.

(13) Gonzalez-Gil, G.; Seghezzo, L.; Lettinga, G.; Kleerebezem, R.; University, W. Biotechnol. Bioeng. 2001, 73 (2), 125-134.

(14) APHA. 2005, Standard Methods for the Examination of Water and Wastewater. 21st edn, American Public Health Association/American Water Works Association/ Water Environment Federation, Washington DC, USA. 
(15) Ripley, L.E.; Boyle, W.C.; Converse, J.C. J Water Pollut Control Federation. 1986, $58(5), 406-411$.

(16) Kitcherside, M.A.; Glen, E.F.; Webster, A.J.F. Anim. Feed Sci. Technol. 2000, 86 $(1-2), 125-132$.

(17) Symons, G.E.; Buswell, A.M. J. Am. Chem. Soc. 1933, 55 (5), 2028-2036.

(18) IFRF. 2011. International Flame Research Foundation Online Combustion Handbook. ISSN 1607-9116. http://www.handbook.ifrf.net/handbook/. last accessed November 2011.

(19) Banks, C.J.; Zhang, Y.; Jiang, Y.; Heaven, S. Bioresour. Technol. 2011, Available online 2 November 2011, ISSN 0960-8524, 10.1016/j.biortech.2011.10.068. (20) Karakashev, D.; Batstone, D.J.; Trably, E.; Angelidaki, I. Appl. Environ. Microbiol. 2006, 72 (7), 5138-5141.

(21) Schnurer, A.; Nordberg, A. Water Sci. Technol. 2008, 57 (5), 735-740.

(22) Ragsdale, S.W.; Pierce, E. Biochim. Biophys. Acta. 2008, 1784 (12), 1873-1898.

(23) Noguera, D.R.; Araki, N.; Rittmann, B.E. Biotechnol. Bioeng. 1994, 44 (9), 10401047.

(24) Kuo, W.C.; Sneve, M.A.; Parkin, G.F. Water Environ. Res. 1996, 68 (3), 279285.

(25) Lin, S.Y.; Dence, C.W. Springer-Verlag, New York. 1992. 
Table 1. OLRs and HRTs studied

\begin{tabular}{lllll}
\hline Digesters & OLR & $\begin{array}{l}\text { Feedstock added } \\
\left(\mathrm{g} \mathrm{VS}^{-1} \mathrm{day}^{-1}\right)\end{array}$ & $\begin{array}{l}\text { Retention } \\
\left(\mathrm{g} \mathrm{VS} \mathrm{day}^{-1}\right)\end{array}$ & $\begin{array}{l}\text { Time } \\
(\text { day })\end{array}$ \\
\hline R1 and R2 & 2.1 & 8.4 & 24 & 166 \\
R3 and R4 & 3.1 & 12.5 & 36 & 111 \\
R5 and R6 & 4 & 16.7 & 48 & 83 \\
R7 and R8 & 5 & 20.9 & 60 & 66 \\
\hline
\end{tabular}


Table 2. Substrate characteristics

\begin{tabular}{|c|c|c|}
\hline & Unit & Winter wheat ${ }^{\mathrm{a}}$ \\
\hline Treatment & & Silage \\
\hline $\mathrm{pH}^{\mathrm{b}}$ & & 4.2 \\
\hline TKN & $\mathrm{g} \mathrm{N} \mathrm{kg}^{-1} \mathrm{WW}$ & 6.4 \\
\hline TAN & $\mathrm{g} \mathrm{N} \mathrm{kg}^{-1} \mathrm{WW}$ & 1.3 \\
\hline TS & $\mathrm{g} \mathrm{kg}^{-1} \mathrm{WW}$ & 363 \\
\hline VS & $\mathrm{g} \mathrm{kg}^{-1} \mathrm{WW}$ & 347 \\
\hline Moisture & $\% \mathrm{WW}$ & 63.7 \\
\hline $\mathrm{CV}$ & $\mathrm{MJ} \mathrm{kg}^{-1} \mathrm{VS}$ & 17.0 \\
\hline $\mathrm{P}$ & $\mathrm{g} \mathrm{kg}^{-1} \mathrm{WW}$ & 0.74 \\
\hline Fibre $(\mathrm{H}+\mathrm{C}+\mathrm{L})$ & $\% \mathrm{TS}$ & 40.0 \\
\hline Fibre $(C+L)$ & $\% \mathrm{TS}$ & 23.8 \\
\hline Fibre (L) & $\%$ TS & 8.9 \\
\hline $\mathrm{K}$ & $\mathrm{g} \mathrm{kg}^{-1} \mathrm{WW}$ & 4.88 \\
\hline $\mathrm{Cd}$ & $\mu \mathrm{g} \mathrm{g}^{-1} \mathrm{TS}$ & 0.40 \\
\hline $\mathrm{Cr}$ & $\mu \mathrm{g} \mathrm{g}^{-1} \mathrm{TS}$ & 104 \\
\hline $\mathrm{Cu}$ & $\mu \mathrm{g} \mathrm{g}^{-1} \mathrm{TS}$ & 37.9 \\
\hline $\mathrm{Ni}$ & $\mu \mathrm{g} \mathrm{g}^{-1} \mathrm{TS}$ & 35.6 \\
\hline $\mathrm{Pb}$ & $\mu \mathrm{g} \mathrm{g}^{-1} \mathrm{TS}$ & 2.21 \\
\hline $\mathrm{Zn}$ & $\mu \mathrm{g} \mathrm{g}^{-1} \mathrm{TS}$ & 172 \\
\hline $\mathrm{C}$ & $\% \mathrm{VS}$ & 46.7 \\
\hline $\mathrm{H}$ & $\% \mathrm{VS}$ & 6.61 \\
\hline
\end{tabular}


Table 3. Energy values for semi-continuous digestion of winter wheat

\begin{tabular}{|c|c|c|}
\hline & Unit & Parameter \\
\hline $\mathrm{CH}_{4}$ yield in $\mathrm{BMP}^{\mathrm{a}}$ & $1 \mathrm{~g}^{-1} \mathrm{VS}_{\text {added }}$ & $0.360 \pm 0.03$ \\
\hline \multirow[t]{2}{*}{$\mathrm{CH}_{4}$ yield in semi-continuous digestion } & $1 \mathrm{~g}^{-1} \mathrm{VS}_{\text {added }}$ & 0.320 \\
\hline & $1 \mathrm{~g}^{-1} \mathrm{VS}_{\text {destroyed }}$ & 0.430 \\
\hline Substrate destruction (semi-continuous) & $\%$ & 75 \\
\hline Empirical formula & & $\mathrm{C}_{29.5} \mathrm{H}_{49.7} \mathrm{O}_{21.3} \mathrm{~N}_{1.0}$ \\
\hline Theoretical $\mathrm{CH}_{4}$ yield (Buswell) & $1 \mathrm{~g}^{-1} \mathrm{VS}$ & 0.451 \\
\hline Theoretical methane content (Buswell) & $\%$ & 51.8 \\
\hline Average measured methane content & $\%$ & 53.0 \\
\hline Calculated CV (Du Long equation) & $\mathrm{MJ} \mathrm{kg}^{-1} \mathrm{VS}$ & 18.4 \\
\hline Measured CV & $\mathrm{MJ} \mathrm{kg}^{-1} \mathrm{VS}$ & 17.0 \\
\hline Energy recovered as $\mathrm{CH}_{4}$ (semi-continuous) & $\mathrm{MJ} \mathrm{kg}{ }^{-1} \mathrm{VS}$ & 12.5 \\
\hline Recovery of measured $\mathrm{CV}$ as $\mathrm{CH}_{4}$ & $\%$ & 73.3 \\
\hline Recovery of calculated $\mathrm{CV}$ as $\mathrm{CH}_{4}$ & $\%$ & 67.8 \\
\hline
\end{tabular}

${ }^{\text {a }}$ Rincón et al. ${ }^{7}$ 


\section{Figure captions}

Figure 1. (1a) pH for R1-6, (1b), alkalinity for R1-4, (1c) alkalinity for R5-6 and (d) IA/PA ratio for R5-6 during the experimental period.

Figure 2. (2a) TKN and modelled TKN nitrogen for R3-4, (2b) measured and modelled TAN for R1-2, (2c) measured and modelled TAN for R3-4 and (2d) measured and modelled TAN for R5-6.

Figure 3. Digestate solids concentration and apparent solids destruction during the experimental period. (3a) Total Solids (TS) for R1-6, (3b) Volatile Solids (VS) for (R16), (3c) Volatile Solids Removed for R1-4 and (3d) Total Solids and Solids Removed for R5-6.

Figure 4. VFA profiles during the experimental period: (4a) R1, (4b) R2, (4c) R3, (4d) R5 and (4e) R6 (Note different axis scales for R1-4 and R5-6).

Figure 5. (5a) Specific methane yield for R1-2, (5b) volumetric biogas production for R1-2, (5c) specific methane yield for R3-4, (5d) volumetric biogas production for R3-4, (5e) specific methane yield for R5-6, (5f) volumetric biogas production for R5-6 during the experimental period (rolling 7-day average). 
Figure 1
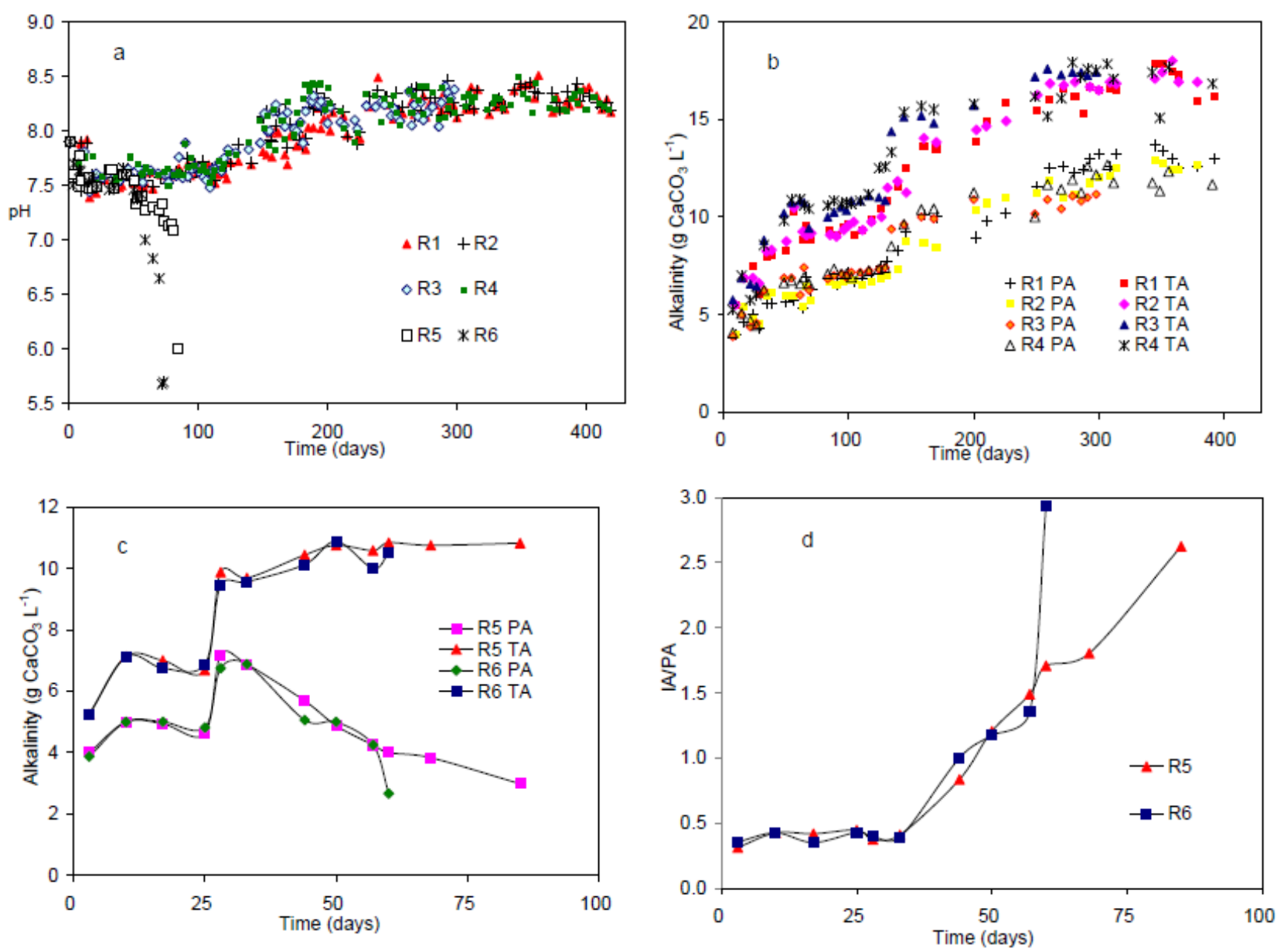
Figure 2
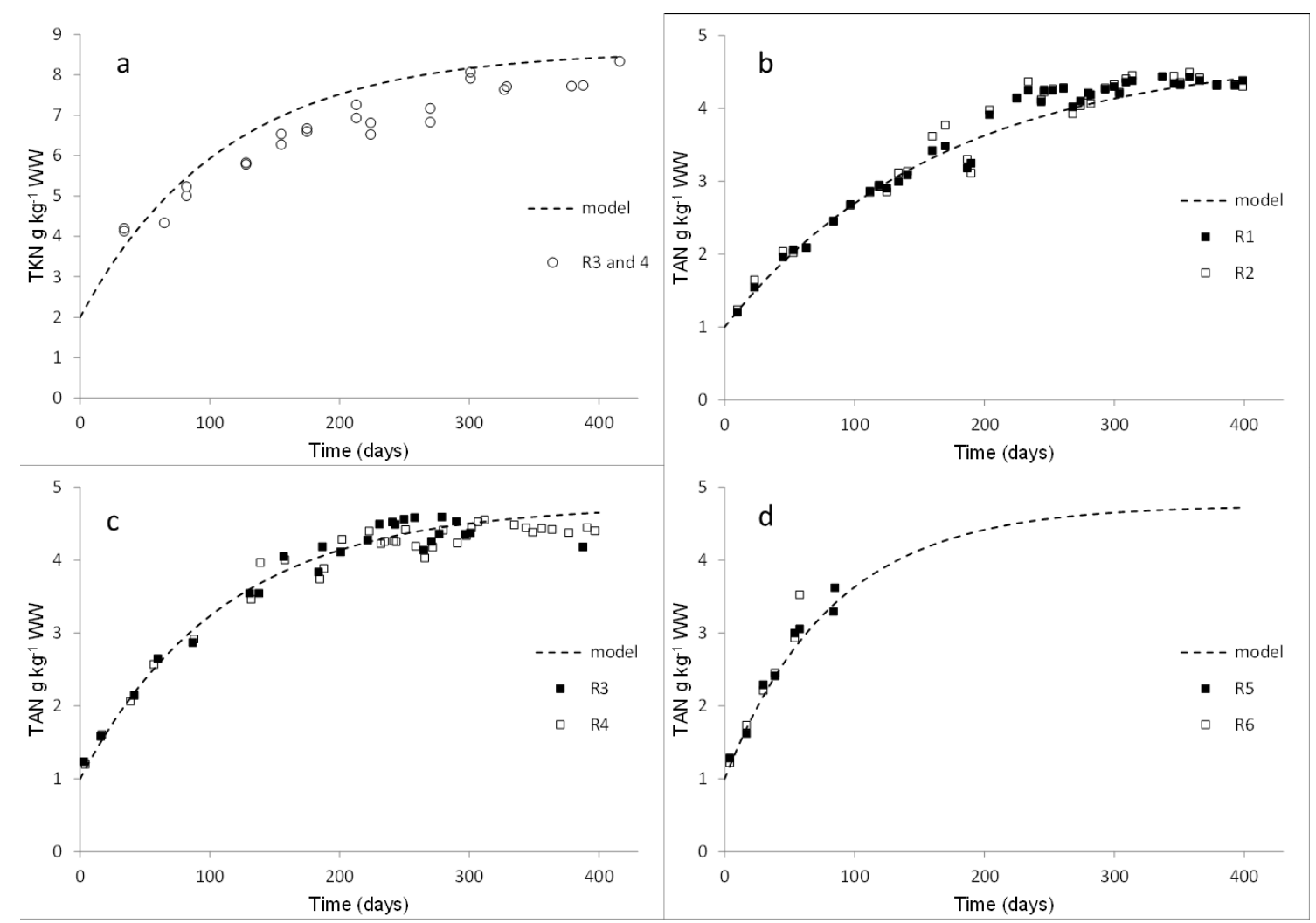
Figure 3
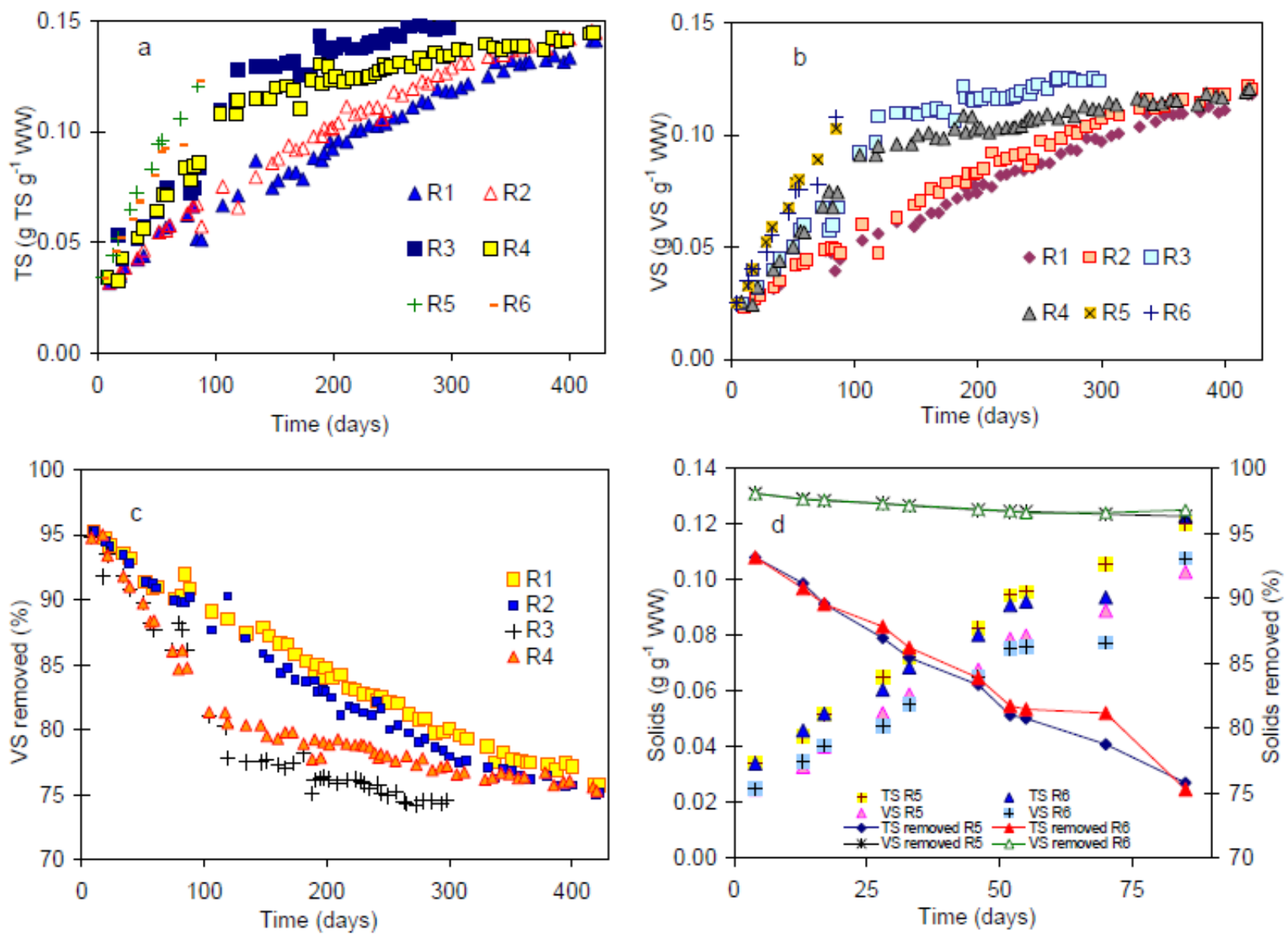
Figure 4
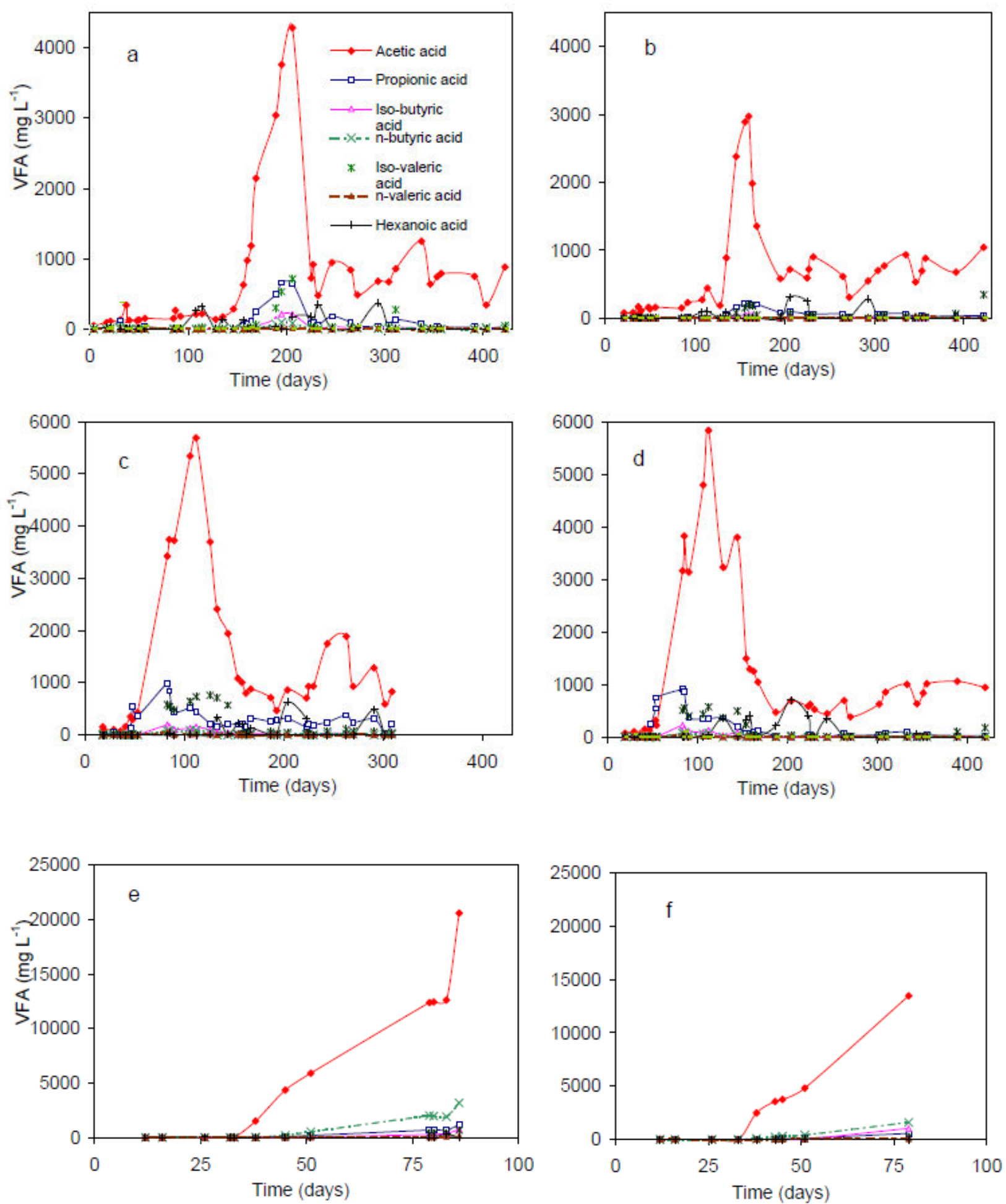
Figure 5
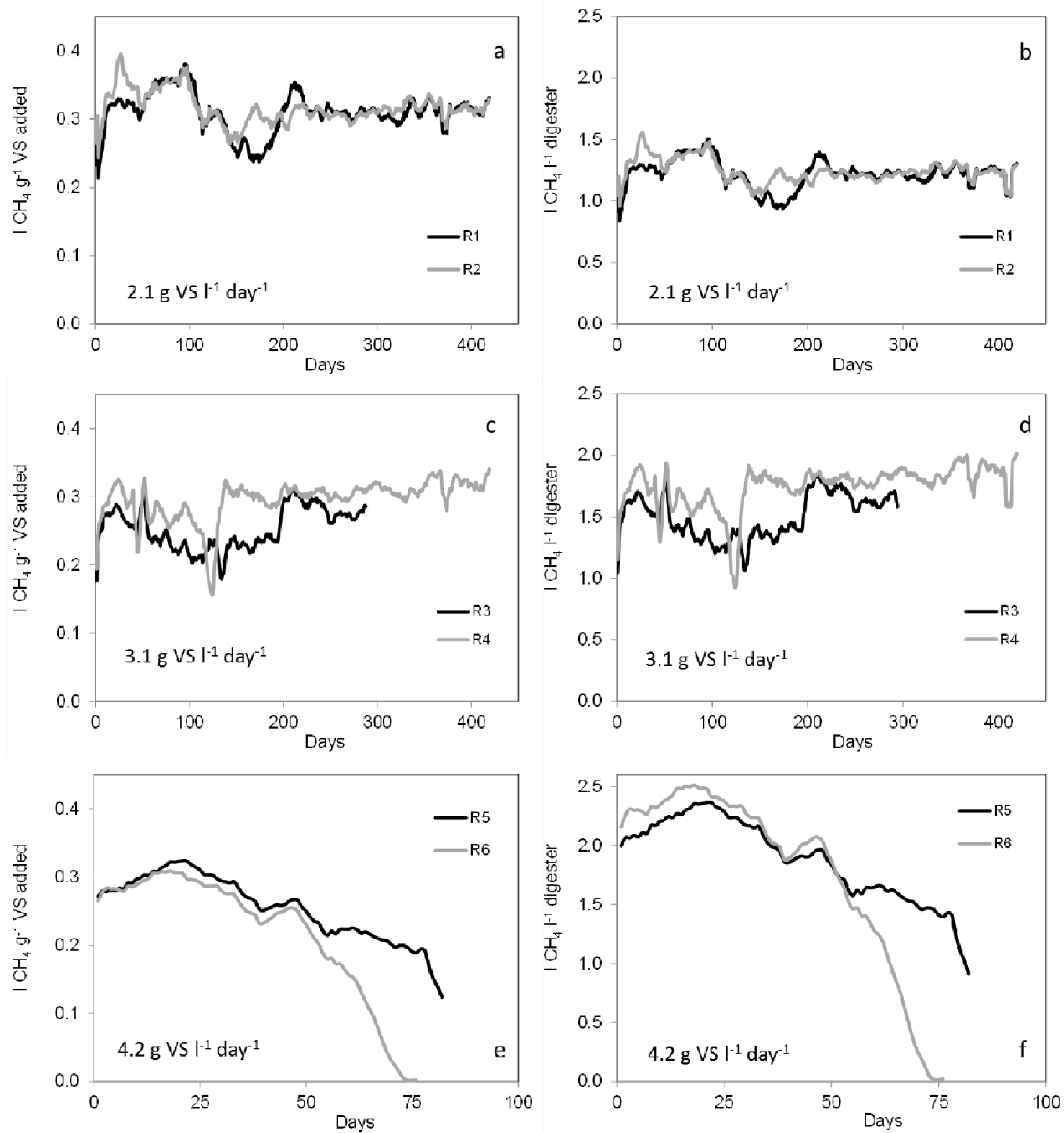